\title{
NEW SPECIES OF PECTIS (ASTERACEAE) FROM THE WEST INDIES, MEXICO, AND SOUTH AMERICA
}

\author{
DAVID J. KEIL
}

\begin{abstract}
Keil, David J. (Biological Sciences Department, California Polytechnic State University, San Luis Obispo, CA 93407). New species of Pectis (Asteraceae) from the West Indies, Mexico, and South America. Brittonia 36: 74-80. 1984.-Four new species of Pectis are described: P. ericifolia from Barbuda, P. luckoviae from west-central Mexico, $\mathbf{P}$. arida from Ecuador and Peru, and P. cajamarcana from Peru. Chromosome counts for P. ericifolia $(n=48)$ and P. luckoviae $(n=12)$ are presented. Relationships of the newly described taxa are discussed.
\end{abstract}

Recent field and herbarium research on the systematics of Pectis (Asteraceae) has resulted in the discovery of four previously undescribed species.

\section{Pectis ericifolia Keil, sp. nov.}

A $P$. tenuicaule Urban et $P$. humifusa Sw. lamina cujusque phyllarii dorso sub apice macula rubescente ornata, ligula cujusque radii dorso vinaceo-maculata, radiorum numero variabile, pappo reducto et chromosomatum numero octoploideo differt. Ulterius a $P$. humifusa minore flosculorum disci numero abstat.

Non-scented fibrous-rooted annual, much-branched from base, mat-forming, seldom radicant. Stems $4-25 \mathrm{~cm}$ long, $0.2-1 \mathrm{~mm}$ diameter, dark purplish, densely leafy with internodes mostly $0.8-2.5 \mathrm{~mm}$ long, hirtellous in decurrent lines with erect whitish trichomes $0.1-0.2 \mathrm{~mm}$ long. Leaves linear oblanceolate, $8-20 \mathrm{~mm}$ long, 2-4 mm broad, at apex rounded and usually mucronulate, glabrous on both surfaces, minutely antrorsely scaberulous on margins toward apex with trichomes 0.1-0.2 mm long, hirtellous proximally on margins with trichomes like those on the stem, ciliate on proximal $1 / 3-1 / 5$ with $3-5$ pairs of bristles $1-2 \mathrm{~mm}$ long, punctate on undersurface with submarginal and scattered circular glands $0.1-0.2 \mathrm{~mm}$ diameter. Heads solitary or in 3-5 headed terminal cymes, subsessile or on peduncles to $5 \mathrm{~mm}$ long, subtended by a pair of opposite foliaceous or scale-like bractlets somewhat smaller than foliage leaves and by a single ovate bractlet $1-2 \mathrm{~mm}$ long. Involucre cylindric, deciduous at maturity with enclosed achenes; phyllaries 3-5, dark green and often with reddish-brown patch near apex, cohering at base and broadly overlapping on margins, oblanceolate to obovate, 5.6-6.6 $\mathrm{mm}$ long, 2.2$3.2 \mathrm{~mm}$ broad, at apex obtuse and sometimes mucronulate, with margins narrowly scarious, minutely erosulate to entire at apex, otherwise entire, on abaxial surface round-keeled nearly to apex, glabrous, punctate near apex with several narrowly elliptic glands $0.1-0.2 \mathrm{~mm}$ long and with similar but smaller submarginal glands that decrease in size toward base. Ray florets 3-5; corollas bright yellow, usually with the tube purplish and the ligule bearing a reddish-purple patch abaxially below apex, 3.2-4.2 $\mathrm{mm}$ long, the tube and ligule subequal, $1.6-2.1 \mathrm{~mm}$ long, glabrous or very sparsely puberulent on the tube with minute gland-tipped trichomes. Disk florets 3-6 (10); corolla bright yellow, 2.2-3 mm long, the tube and throat each 0.8-1.2 mm long, the limb 5-lobed, weakly bilabiate with the anterior lip ca $3 \times$ as long as the lobes on the posterior lip, glabrous to sparsely puberulent with minute gland-tipped trichomes; style 2.4-3.6 mm long, barely exserted; anthers 0.7-0.8 mm long; pollen grains 34-36 $\mu \mathrm{m}$ diameter. Ray achenes 2.9$3.6 \mathrm{~mm}$ long, blackish, adaxially puberulent with ascending whitish bicellular trichomes $0.2-0.3 \mathrm{~mm}$ long, abaxially glabrous, at apex just below pappus bearing brownish gland-tipped multicellular trichomes ca $0.1 \mathrm{~mm}$ long. Disk achenes $2.8-$ $3.2 \mathrm{~mm}$ long, puberulent throughout with bicellular trichomes $0.2-0.3 \mathrm{~mm}$ long, 
TABLE I

Chromosome counts of Pectis ericifolia And P. luckoviae

\begin{tabular}{ccl}
\hline \hline Taxon & Chromosome count & \multicolumn{1}{c}{ Voucher } \\
\hline$P$. ericifolia & $2 n=48 \mathrm{II}$ & Keil 16561 A, B, C, D \\
$P$. luckoviae & $2 n=12 \mathrm{II}$ & Keil \& Luckow 15270 B, C \\
& $2 n=12 \mathrm{II}$ & Keil \& Luckow 15278A \\
\hline
\end{tabular}

and at apex with gland-tipped trichomes. Pappus usually included in involucre at anthesis; ray pappus a crown of low scales $0.2-0.8 \mathrm{~mm}$ long; disk pappus double with $0-4$ bristle-tipped scales up to $3.2 \mathrm{~mm}$ long and 1 to 5 minute scales or reduced bristles $0.2-0.8 \mathrm{~mm}$ long. Chromosome number: $n=48$ (Table I).

TYPE: WEST INDIES. B.W.I.: BARBUDA: $\mathrm{S}$ of Codrington along sand road to Palmetto Point within sight of Martello Tower, near sea level, 29 Nov 1982, D. Keil 16561 (HOLOTYPE: UC; ISOTYPES: ASU, F, FTG, GH, MO, IJ, NY, OBI, OS, TEX, US).

Pectis ericifolia is known only from low-elevation sandy areas at the southern end of Barbuda, a flat, 62 square mile island in the Lesser Antilles. The specific epithet alludes to the resemblance between the leaves of this species and those of some species of Erica (Ericaceae).

\footnotetext{
Other specimens examined: WEST INDIES. B.W.I.: BARBUDA: along sand road about halfway between Martello Tower [at turnoff to Palmetto Point] and Coco Point along W side of island a few meters inland from beach, 29 Nov 1982, Keil 16569; Barbuda: without location, 27 Apr 1959, Cowan 1663 (GH, US).
}

Pectis ericifolia is the first known octoploid species of Pectis. Meiotic chromosome counts $(2 n=48$ II) were obtained from four individuals of the type collection (Keil $16561 A, B, C, D$ ). It is probably an amphiploid hybrid of $P$. tenuicaulis Urban, a diploid $(n=12)$ and a hexaploid $(n=36)$ species. The only hexaploid taxon presently known from the West Indies is P. humifusa Sw. Pectis tenuicaulis typically has 3-rayed heads (rarely 2-rayed), and P. humifusa has 5-rayed heads (rarely 3-rayed; Urban, 1905). The heads of $P$. ericifolia vary from 3-rayed to 5-rayed, sometimes on the same individual. An extra phyllary that does not subtend a ray floret is sometimes present in the 3-rayed and 4-rayed heads. This is very unusual in Pectis.

A collection of $P$. ericifolia by R. S. Cowan (1663) first drew my attention to this species. Cowan's specimens all have 5-rayed heads with ca 10 disk florets and a very reduced pappus. None of the specimens that I collected in 1982 exactly matched his specimens. Pectis ericifolia grows together with $P$. tenuicaulis at the type locality. The two were easy to distinguish by means of the slightly larger heads of $P$. ericifolia that bear reddish patches on the abaxial surfaces of the phyllaries and ray florets. Pectis tenuicaulis has uniformly colored phyllaries and ray corollas.

Pectis humifusa was not located during the brief period available for field work on Barbuda. (It is very likely present, but my search was cut short by extremely inclement weather.) It is present on Antigua (50 km away). At times of eustatic lowering of sea level during the Pleistocene a broad shelf surrounding Antigua and Barbuda was exposed and the two islands were united as a single larger island (Daly, 1963).

Although $P$. tenuicaulis and $P$. humifusa are both widespread in the West Indies, Barbuda is the only island where they are suspected of hybridization. Both taxa are apparently facultatively autogamous (Keil, unpubl.) and are unlikely to hybridize unless they are growing in close proximity. On other islands where both 
species occur (e.g., Martinique and Puerto Rico), they are not known to grow together.

Pectis ericifolia is also probably facultatively autogamous. It has a low pollenovule ratio (ca 344:1) and an outcrossing index of 2, both used by Cruden (1977) as indicators of facultative autogamy. Its seed set is nearly 100 percent, a feature it shares with taxa known to be autogamous [e.g., P. cylindrica (Fern.) Rydb.; Keil, 1975], and in sharp contrast to the much lower seed set of species suspected of being xenogamous [e.g., P. multiflosculosa (DC.) Schultz-Bip. in Seemann]. Attempts are underway to test the inferred self-fertility of $P$. ericifolia in greenhouse experiments.

\section{Pectis luckoviae Keil, sp. nov.}

Una cum $P$. decemcarinata McVaugh a caeteris congeneribus pseudoreceptaculo e phyllariorum basibus induratis connatis cum achaeniorum disci carpopodiis concretis constante differt. A $P$. decemcarinata capitulis majoribus distincte pedunculatis nec dense aggregatis differt.

Annual with slender taproot or occasionally apparently perennial with coarse woody taproot; herbage faintly scented. Stems branched from the base, prostrate to ascending, 3-40 cm long, with internodes usually $1-4 \mathrm{~cm}$ long, puberulent with spreading to recurved trichomes $0.1-0.2 \mathrm{~mm}$ long, the hairs in decurrent lines or uniformly distributed. Leaves linear to very narrowly linear-lanceolate, $1-2.5 \mathrm{~cm}$ long, 1-2.5 $\mathrm{mm}$ broad, often revolute and appearing narrower, on the proximal $1 / 5-1 / 3$ of the margin bearing $3-5$ pairs of bristles $2-4 \mathrm{~mm}$ long, on the adaxial surface densely antrorsely hispidulous with trichomes up to $0.3 \mathrm{~mm}$ long, abaxially on the midrib scaberulous to pilosulous with trichomes up to $0.3 \mathrm{~mm}$ long, punctate on the undersurface with scattered circular oil glands $0.1-0.2 \mathrm{~mm}$ diameter. Heads solitary, terminal, or in 3-5 headed cymes. Peduncles $0.5-4 \mathrm{~cm}$ long, densely puberulent. Bractlets 1-4, alternate, scarious, linear to lanceolate, attenuate, $2-5 \mathrm{~mm}$ long, marginally ciliolate, sometimes bearing 1 or 2 bristles 0.5-1.5 mm long. Receptacle convex or sometimes depressed at summit, ca 1 $\mathrm{mm}$ tall, glabrous. Involucre broadly fusiform to campanulate, green to brownish, with the bases of the phyllaries connate into an indurate 5-lobed ring that is adnate to the connate carpopodia of the disk achenes forming a glandular-puberulent pseudoreceptacle that is deciduous at maturity from the true receptacle, the entire head thus falling as a unit. Phyllaries 5, coriaceous, oblancolate to obovate, 6-8 $\mathrm{mm}$ long, 2-3 $\mathrm{mm}$ broad, connate in the basal $1 \mathrm{~mm}$, quincuncial above, weakly to strongly conduplicate, the apex subacute to retuse, squarrose, minutely ciliolate to glabrate, the base shallowly subcordate, the abaxial surface longitudinally manynerved with a prominent arcuate midrib, in age incrassate forming a protruding corky ridge with numerous deep glandular pits, lightly puberulent on the midrib when young, in age glabrate. Ray florets 5; corollas yellow, sometimes reddened on the abaxial surface, 5-8 $\mathrm{mm}$ long with the tube $2 \mathrm{~mm}$ long, with the ligule elliptic, 3-6 $\mathrm{mm}$ long and $1.5-2.5 \mathrm{~mm}$ broad, glabrous to sparsely glandularpuberulent on the tube and lower portions of the ligule. Disk florets 14-20; corollas yellow, 4.5-6 mm long, with tube $1-1.5 \mathrm{~mm}$ long, the throat $1 \mathrm{~mm}$ long, and the limb $2.5-3.5 \mathrm{~mm}$ long, deeply bilabiate with the anterior lip 3-3.5 $\mathrm{mm}$ long, $0.2-$ $0.3 \mathrm{~mm}$ broad, $7-8 \times$ as long as the 4 lobes on the posterior lip, sparsely glandularpuberulent on the throat and ciliolate with eglandular trichomes on the margins of the lips, papillose at the apices of the lobes; style equalling the corolla; anthers ca $2 \mathrm{~mm}$ long; pollen grains 29-30 $\mu \mathrm{m}$ diameter. Ray achenes 3.5-4.5 mm long, slightly arcuate, abaxially glabrous, adaxially pilose with ascending whitish trichomes up to $1 \mathrm{~mm}$ long. Disk achenes 3-4 mm long, straight, pilose in vertical lines with ascending whitish trichomes up to $0.6 \mathrm{~mm}$ long. Pappus of both ray 


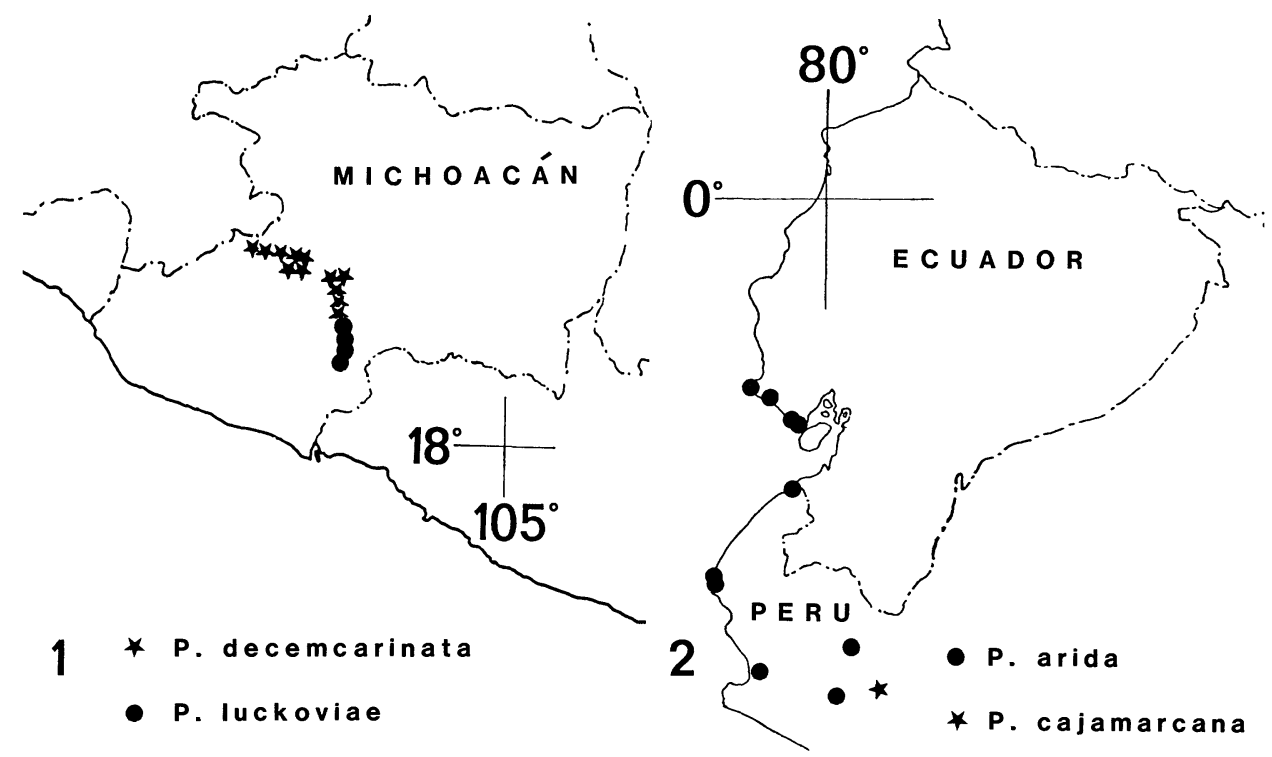

FIgs. 1-2. 1. Distribution of Pectis lukoviae (circles) and P. decemcarinata (stars) in the Río Tepalcatepec basin of Michoacán, Mexico. 2. Distribution of $P$. arlda (circles) and $P$. cajamarcana (star) in Ecuador and Peru.

and disk achenes similar, of 2 (ray) or 5 (disk) lacerate-margined membranous scales $0.8-1.5 \mathrm{~mm}$ long. Chromosome number: $n=12$ (Table I).

TYPE: MEXICO. MichoACÁN: $1.3 \mathrm{mi} \mathrm{S}$ of Nuevo Centro, $5.7 \mathrm{mi} \mathrm{N}$ of Los Pocitos on Rte 37, dry thorn forest with short grass understory, elev. $800 \mathrm{ft}, 31$ Aug 1981, D. Keil \& M. Luckow 15270 (HOLOTYPE: UC; ISOTYPES: ASU, ENCB, F, GH, MEXU, MO, NY, OBI, OS, TEX).

Pectis luckoviae is known only from a small area of southern Michoacán west of the confluence of the Río Tepalcatepec and Río Balsas (Fig. 1). It is locally abundant in dry thorn-forest from 250 to $450 \mathrm{~m}$ elevation. This species is named in honor of Melissa Luckow who accompanied me on the expedition during which $P$. luckoviae was discovered.

Other specimens examined: MEXICO. MichoACÁN: $4.8 \mathrm{mi} \mathrm{S}$ of Nuevo Centro, 31 Aug 1981, Keil \& Luckow 15272 (INF, MEXU, OBI); $2.3 \mathrm{mi} \mathrm{S}$ of Los Pocitos, 31 Aug 1981, Keil \& Luckow 15273 (OBI); $1.1 \mathrm{mi} \mathrm{N}$ of Las Canas, 31 Aug 1981, Keil \& Luckow 15274 (OBI); $2.3 \mathrm{mi} \mathrm{S}$ of Las Canas, 31 Aug 1981, Keil \& Luckow 15275 (OBI, TEX, UCR); $4 \mathrm{mi} \mathrm{N}$ of El Guayabito, 31 Aug 1981, Keil \& Luckow 15277 (OBI); El Guayabito, 31 Aug 1981, Keil \& Luckow 15278 (OBI).

Pectis luckoviae is closely related to $P$. decemcarinata McVaugh, a species also endemic to the Río Tepalcatepec basin of Michoacán (Fig. 1). The southernmost known population of $P$. decemcarinata occurs about two miles north of the northernmost known populations of $P$. luckoviae. The feature that unites these species and distinguishes them from all other species of Pectis is the pseudoreceptacle composed of the sclerified bases of the phyllaries and the connate carpopodia of the disk achenes. Although several other Pectis species have weakly coherent phyllaries that fall as a unit together with the enclosed achenes (e.g., P. prostrata Cav., P. cylindrica, and P. tenuicaulis), none of them have carpopodia connate and adnate to the phyllary bases. Pectis luckoviae differs from $P$. decemcarinata in having 1 to 5 comparatively large heads per branch rather than 5 to 20 or more 
small densely aggregated heads. No evidence is available of any intergradation between these taxa although their ranges are almost contiguous.

Two other taxa of Pectis were collected from sites where P. luckoviae was growing: P. linifolia L. var. hirtella S. F. Blake, and P. uniaristata DC. var. uniaristata. No evidence of hybridization was found.

\section{Pectis arida Keil, sp. nov.}

A P. ciliare L. cui simillima est foliorum phyllariorumque glandulis majoribus, foliis tenuibus, phyllariis angustis et elementis pappi magis numerosis distinguitur.

Taprooted annual, probably scented but nature of scent unknown. Stems erect or ascending, solitary or 2-5-branched from near base, 5-20 cm long, stramineous or purplish, puberulent with retrorsely curved, multicellular trichomes ca $0.1 \mathrm{~mm}$ long. Leaves linear, 2-4 cm long, 2-3 mm broad, mucronate or setose-tipped, proximally ciliate to about the middle with bristles ca $2 \mathrm{~mm}$ long, sparsely puberulent abaxially on the midrib with trichomes ca $0.1 \mathrm{~mm}$ long, minutely scaberulous along margins, otherwise glabrous, densely punctate on the undersurface with round glands $0.1-0.3 \mathrm{~mm}$ diameter. Heads short-peduncled from the forks of the stems and at stem apices, solitary or becoming cymose-clustered in age. Peduncles 1-32 mm long, puberulent, bearing 1 or 2 alternate, scale-like to foliaceous setose-tipped bractlets $2-4 \mathrm{~mm}$ long. Involucres cylindric to narrowly campanulate; phyllaries 5-7, oblong-oblanceolate, 5-6 $\mathrm{mm}$ long, 1-1.5 $\mathrm{mm}$ broad, obtuse to subacute, on abaxial surface convex, keeled to above the middle, dotted or streaked with numerous scattered elliptical to linear glands $0.2-0.6 \mathrm{~mm}$ long, near apex and streaked with linear glands proximally, thin-margined, minutely glandular-ciliolate, otherwise glabrous. Ray florets 5-7; corollas yellow or reddening in age, 4-5 mm long with tubes $1.5-1.8 \mathrm{~mm}$ long and ligules $2.5-3.2 \mathrm{~mm}$ long. Disk florets 10-15; corollas yellow, 2.5-3 mm long, 4- or 5-lobed, weakly bilabiate, with the anterior lip $0.6-0.7 \mathrm{~mm}$ long, ca $2-3 \times$ the length of the lobes on the posterior lip; style about equalling the corolla; anthers ca $0.6-0.7 \mathrm{~mm}$ long; pollen grains 34-40 $\mu \mathrm{m}$ diameter. Achenes 3-4 mm long, uniformly strigose with bifurcate 2-celled trichomes $0.15-0.25 \mathrm{~mm}$ long and just below insertion of pappus bearing multicellular gland-tipped trichomes ca $0.1 \mathrm{~mm}$ long. Ray pappus of 2 or 3 paleaceous-based awns 3-4 mm long, often with several short bristles or scales 0.5-1 mm long inserted abaxially between the awns; disk pappus of 15-20 unequal antrorsely barbed bristles $2-4 \mathrm{~mm}$ long, these sometimes paleaceous based. Chromosome number: unknown.

Type: ECUADOR. GuAyas: Puntilla, Salinas, 21 Feb 1941, H. K. Svenson 11124 (HOLOTYPE: UC; ISOTYPE: US).

Pectis arida is known only from a narrow strip of coastal lowlands of southwestern Ecuador and northwestern Peru, ranging from near sea level to ca 300 meters elevation (Fig. 2). It is named for the very xeric environment in which some populations occur.

Other specimens examined: ECUADOR. GUAYAs: El Recreo, 18 Apr 1897, Eggers 15785 (F, GH, US); Pacific coast W of Punta Carnero, 12 Mar 1973, Holm-Nielsen et al. 2013 (F); between Ancon and Atahualpa, 17 Mar 1973, Holm-Nielsen et al. 2108 (F); Chanduy, 18 Mar 1973, Holm-Nielsen et al. 2117 (F); ad Playas, Apr 1928, Mille 192 (US); ad Pasorja, Feb 1933, Mille 782 (US); ad Bahia, Jan 1940, Mille 1945 (US); Salinas, 15 Mar 1941, Svenson 11209 (GH, US). PERU. LAMBAYEQUE: Olmos, 4 May 1957, Ellenberg 1259 (US). PiURA: Nigritos, Mar 1926, Haught F-47 (F); Km 1130 Carretera Piura-Tumbes, 19 Apr 1949, Ferreyra 5935 [mixed with Pectis cryptopetala Schultz-Bip. in Seemann] (US); $60 \mathrm{~km} \mathrm{~S}$ of Piura, 30 Apr 1949, Ferreyra 6024 (US); Talara, 1927, Haught 143 (US); Huancabamba, Serrán, 2 Apr 1939, Stork 11368 [mixed with P. cryptopetala] (GH); Serrán, 1909-1914, A. Weberbauer 5989 (F, GH, US). Tumbes: Zarumilla, entre Zarumilla y Aguas Verdes, 25 Apr 1955, Ferreyra, Cerrate \& Tovar 10613 (OBI). 
The resemblance that this species has to $P$. ciliaris L., a West-Indian taxon, is superficial and probably does not indicate a close relationship. Pectis arida has the thin leaves and prominent glands common in the strongly scented Pectis species of the deserts of North and South America. None of the labels on specimens examined of $P$. arida had a notation of odor, but this is not at all unusual. Few herbarium labels bear any information regarding plant odor, even though this can be taxonomically informative. Pectis ciliaris has very small glands and the gland contents are not scented. Its leaves are of a coarser texture than those of $P$. arida.

\section{Pectis cajamarcana Keil, sp. nov.}

A $P$. peruviana Keil capitulis quinqueradiatis longius pedunculatis, phyllariis latioribus, flosculis disci magis numerosis differt.

Annual, probably scented but nature of scent unknown. Stems several from the base, $10-15 \mathrm{~cm}$ long, densely puberulent with retrorsely curled trichomes, stramineous to purplish. Leaves lance-linear, $1-2.5 \mathrm{~cm}$ long, 1-2.2 $\mathrm{mm}$ broad, acute, mucronate or bristle-tipped, proximally ciliate to about the middle with bristles 2-4 mm long, glabrous or sparsely puberulent abaxially on the midrib with numerous round glands ca $0.2 \mathrm{~mm}$ diameter. Heads solitary at branch-tips, becoming cymosely clustered with age. Peduncles 3.5-4.5 mm long, puberulent, with 4-7 scattered setiform bractlets or the lowermost somewhat foliaceous. Involucres campanulate; phyllaries 5, narrowly obovate, 6-7 $\mathrm{mm}$ long, 2-2.5 $\mathrm{mm}$ broad, acute with the abaxial surface strongly convex, keeled nearly to the apex, narrowly hyaline margined, sparsely puberulent near the apex, otherwise glabrous, streaked longitudinally with numerous linear glands. Ray florets 5; corollas yellow, $7 \mathrm{~mm}$ long, with the tube $2 \mathrm{~mm}$ long, and ligule $5 \mathrm{~mm}$ long, glabrous. Disk florets ca 20; corollas $4 \mathrm{~mm}$ long, yellow, bilabiate with the anterior lip $1 \mathrm{~mm}$ long, ca $2 \times$ the length of the lobes of the posterior lip, glabrous; anthers $1.2-1.5 \mathrm{~mm}$ long; pollen grains ca $32 \mu \mathrm{m}$ diameter. Achenes of ray and disk similar, $4-4.5 \mathrm{~mm}$ long, strigillose or pilosulous with blunt-tipped bicellular trichomes $0.25-0.3 \mathrm{~mm}$ long. Pappus of ray and disk similar, of 30-40 antrorsely barbed bristles 3-4.5 mm long. Chromosome number: unknown.

TyPE: PERU. CajAmarCa: Jaén: Pucará (on Río Huancabampa), hilltop NW of town, 1100 m, 17 Jan 1964, P. C. Hutchison \& J. K. Wright 3579 (HOLOTYPE: UC; ISOTYPES: F, MO, NY, US, USM).

Pectis cajamarcana is apparently most closely related to another poorly known Peruvian taxon, $P$. peruviana Keil. The two taxa have similar foliage and both have a multisetose pappus on both ray and disk achenes. Pectis peruviana has 8-rayed heads with narrower phyllaries than $P$. cajamarcana and about half as many disk florets. The specific epithet is derived from Cajamarca, the name of the Peruvian province where the type specimens were collected.

Other specimen examined: PERU. Cajamarca: $6 \mathrm{~km}$ E of Pucará, 860 m, 11 Jun 1978, Gentry, Dillon, Aronson \& Diaz 22709 (MO).

\section{Acknowledgments}

This research was supported by NSF Grant no. DEB 81-04683. Thanks are given to Melissa Luckow for her assistance in field and laboratory investigations.

\section{Literature Cited}

Cruden, R. W. 1977. Pollen-ovule ratios: a conservative indicator of breeding systems in flowering plants. Evolution 31: 32-46. 
Daly, R. A. 1963. The changing world of the ice age. Hafner Publ. Co., New York and London. 271 pp.

Keil, D. J. 1975. Pectis cylindrica (Compositae) established as a member of the Texas flora and confirmed as a distinct species. Southw. Naturalist 20: 286-287.

Urban, I. 1905. Compositarum genera nonnulla. Symbolae Antil. 5: 212-286. 